\title{
Analysis of customer satisfaction to quality of service using Importance Performance Analysis (IPA) on PT. Telekomunikasi Indonesia. (Case study Telkom Divre IV Central Java \& Yogyakarta)
}

\author{
Arlita Rahma Widyasrini ${ }^{1, *}$ and Nia Budi Puspitasari ${ }^{1}$ \\ ${ }^{1}$ Industrial Engineering Department, Diponegoro University, Semarang, Central Java, Indonesia
}

\begin{abstract}
PT. Telekomunikasi Indonesia, Tbk. (PT.Telkom) always serve to provide the best service to customers. Analysis of company performance based on customer satisfaction with the results of research can be done service improvements that are not in accordance with customer expectations and foster customer loyalty and improve the competitiveness of the company PT. Telkom Divre IV Central Java \& Yogyakarta. The number of fast subscribers for the $201 \mathrm{X}$ period is 252,946 calls. Total quantity of product in Semarang if compared to quantity, if in the long term can cause customer dissatisfaction which resulted the change of customer to company, hence needed analysis which aim for service quality, service quality service analysis perceived by customer, and analysis the level of customer satisfaction PT. Telkom Divre IV Central Java \& Yogyakarta. The method used in measuring consumer satisfaction is the method of Importance Performance Analysis (IPA), comparing the expectation of customers with the performance of the company. The use of IPA methods can identify attributes with poor and existing performance from users, and determine the steps of important attributes that still have poor performance, thus the results of the study provide recommendations to PT. Telkom Divre IV Central Java \& Yogyakarta.
\end{abstract}

\section{Introduction}

In the global era, manufacturing and service companies must face tough competition with existing companies. The company creates its own advantages to compete with its competitors. The company seeks to improve the services provided to customers.

PT. Telekomunikasi Indonesia, Tbk. (PT.Telkom) is one of the companies engaged in telecommunications services. Competition in the telecommunication service industry is very tight to make PT. Telkom always committed to keep trying to give the best service to the customer. PT. Telkom strives to continuously always improve the quality of its performance in order to exist and excel compared with its competitors. Steps to know the service of PT. Telkom has been in accordance with customer needs that is by looking at the

*Corresponding email: arlitarahma.w@gmail.com 
number of complaints. Graphic number of consumer complaints in Semarang about Speedy products that go to PT. Telkom in the period 201X can be seen in Figure 1:

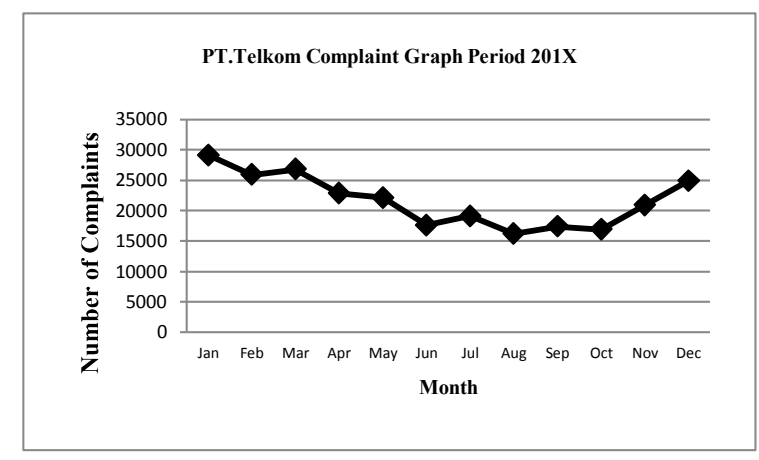

Figure 1. PT.Telkom Complaint Graph Period 201X.

Based on Figure 1 shows that the number of complaints from consumers domiciled Semarang in 201X each month decreased. Overall number of complaints in 201X amounted to 252,946 . Consumer complaints data domiciled Semarang about TelkomSpeedy period 201X which has been divided by type of complaint can be seen in Table 1 .

Table 1. Formatting sections, subsections and subsubsections.

\begin{tabular}{lcc}
\hline \multicolumn{1}{c}{ Complaint Type } & Amou & Percentag \\
& ent & $4,58 \%$ \\
\hline Connections are often disconnected & 11.586 & $5,59 \%$ \\
Slow Speed & 14.128 & $8,71 \%$ \\
Can not browse & 22.03 & $73,53 \%$ \\
Can not connect & 185.98 & $0,16 \%$ \\
Modem has not arrived yet & 7 & $7,43 \%$ \\
Etc & 410 & $100 \%$ \\
\hline \multirow{2}{*}{ Total } & 18.805 & \\
\hline
\end{tabular}

Based on table 1. shows one customer can do more than one complaint in one period. Total number of users of TelkomSpeedy products in the city of Semarang, which is 40,596 people. The number of complaints is far more than the number of users of the product when compared in terms of quantity, there are still many consumers who are not satisfied because of the discrepancy of consumer expectations of TelkomSpeedy service. From the number of customer complaints if in the long run occurs continuously may cause customer dissatisfaction resulting in the shift of customers to similar services from other companies.

Improving the quality of service becomes a very important thing for the company to provide value and customer satisfaction. Quality of service has five main dimensions of services that can be used to measure the level of customer satisfaction is tangible, reliability, responsiveness, assurance, empathy [1]. The method used in measuring consumer satisfaction is Importance Performance Analysis (IPA) [2]. The method is used PT. Telkom to compare expectations with what customers receive or company performance. IPA methods can identify attributes with poor performance and complaints from users, and determine the corrective steps of the attributes that are considered important that still have poor performance, so that customers continue to use the services of PT. Telkom Divre IV Central Java \& Yogyakarta. 
The purpose of this study is to analyze the level of customer expectations of service quality, analyze the performance of service quality perceived by customers, and analyze the level of customer satisfaction PT. Telkom Divre IV Central Java \& Yogyakarta.

\section{Material and Methods}

Research method of customer satisfaction analysis to service quality by using Importance Performance Analysis (IPA) at PT. Telekomunikasi Indonesia, begins with the formulation of problems and research objectives, the research objectives are determined from the formulation of problems that have been identified.

Literature study and preliminary observation. The literature study is conducted to gather as many theories, sciences, data, or information as possible with the analysis of customer satisfaction on service quality using the Importance Performance Analysis (IPA) method. Quality of service centered on efforts to meet the needs and desires of customers and the accuracy of delivery to compensate for customer expectations. There are two main factors that affect the quality of services, the expected service and perceived service. The main dimensions of service quality are arranged in order of their relative importance [3], among others, tangibles, reliability, responsiveness, assurance and empathy.

The Importance Performance Analysis (IPA) method can be started by identifying the initial attributes, identifying the importance level (expectancy) of each attribute and identifying the performance in each attribute. Second, determine the advantages and disadvantages of service with quadrant analysis. Counting the number of incoming questionnaires. Test the reliability and validity of the items with the Microsoft Excel tool. Determining the level of respondent's suitability. Determining the average score of the level of execution / satisfaction and importance level. Determining $\mathrm{X}$ is the average of the average score of the level of implementation / satisfaction over all factors or attributes and $\mathrm{Y}$ is the average of the importance level score of all factors that affect customer satisfaction. Elaborate the level of these elements into four parts of Cartesian diagram. Cartesian diagram can be seen in Figure 2.

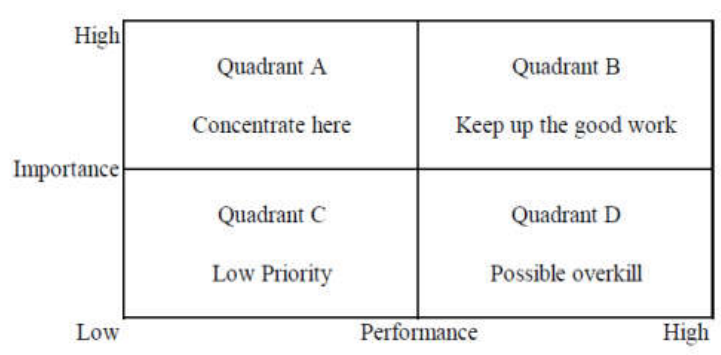

Fig. 2. Cartesian diagram.

Quadrant A shows the service factors or attributes that are considered to affect customer satisfaction including the elements of services that are considered very important, but the management has not implemented in accordance with the wishes of customers to disappointed customers. Quadrant B, indicating the element of service that has been successfully implemented company, for it must be maintained. Considered very important and very satisfying. Quadrant C, shows several factors that are less important to the customer. Implementation by the company mediocre. Considered less important and less satisfactory. Quadrant D, indicating factors that affect customers is less important, but the implementation of the important remains very satisfactory.

Identification of initial research attributes, determination of sample research with Taro Yamane method. One method used to determine the number of samples with known numbers [4]. 


$$
n=\frac{N}{1+N d^{2}}
$$

Where $\mathrm{n}$ is the number of samples, $\mathrm{N}$ is the population number, and $\mathrm{d}$ is the margin error.

\subsection{Identity Attributes}

Identification of attributes is done through literature study by looking for previous studies on the satisfaction of service users of PT. Telkom. From this literature study obtained 24 initial attributes of user satisfaction services PT. Telkom. These initial attributes are used as a basis for the preparation of the questionnaire.

Table 2. Initial Attribute Satisfaction User Service PT. Telkom.

\begin{tabular}{|c|c|c|c|c|}
\hline Dimensions & Code & No & $\begin{array}{l}\text { Service Attribute } \\
\end{array}$ & Source \\
\hline \multirow{6}{*}{ Tangible } & T1 & 1 & PT. Telkom uses up-to-date equipment in every work & [5] \\
\hline & $\mathrm{T} 2$ & 2 & $\begin{array}{l}\text { The quality of the project result is satisfactory (eg. } \\
\text { neat) }\end{array}$ & [6] \\
\hline & $\mathrm{T} 3$ & 3 & $\begin{array}{l}\text { Employees of PT. Telkom wears polite and neat } \\
\text { clothes when we work }\end{array}$ & [5] \\
\hline & $\mathrm{T} 4$ & 4 & $\begin{array}{l}\text { Results of work in accordance with the initial } \\
\text { agreement }\end{array}$ & [7] \\
\hline & T5 & 5 & The office physical facilities are attractive & [7] \\
\hline & T6 & 6 & The lounge area is comfortable & [7] \\
\hline \multirow{6}{*}{ Reliability } & RE1 & 7 & $\begin{array}{l}\text { Employees of PT. Telkom is friendly in providing } \\
\text { services }\end{array}$ & [8] \\
\hline & RE2 & 8 & $\begin{array}{l}\text { Employees of PT. Telkom is friendly in responding } \\
\text { to customer complaints }\end{array}$ & [8] \\
\hline & RE3 & 9 & $\begin{array}{l}\text { Employees of PT. Telkom serves quickly and } \\
\text { thoroughly }\end{array}$ & [8] \\
\hline & RE4 & 10 & $\begin{array}{l}\text { PT.Telkom employees are professional towards the } \\
\text { wants and demands of consumers }\end{array}$ & [8] \\
\hline & RE5 & 11 & $\begin{array}{l}\text { PT. Telkom provides a variety of products that can be } \\
\text { made a choice of products for customers }\end{array}$ & [9] \\
\hline & RE6 & 12 & $\begin{array}{l}\text { PT. Telkom is reliable compared to similar } \\
\text { competitors }\end{array}$ & [5] \\
\hline \multirow{3}{*}{$\begin{array}{l}\text { Responsive } \\
\text { ness }\end{array}$} & R1 & 13 & $\begin{array}{l}\text { Ease in obtaining information about products and } \\
\text { services provided }\end{array}$ & [6] \\
\hline & R2 & 14 & $\begin{array}{l}\text { Employees of PT. Telkom is always willing to help } \\
\text { consumers }\end{array}$ & [5] \\
\hline & R3 & 15 & $\begin{array}{l}\text { PT. Telkom responds to requests and complaints } \\
\text { quickly }\end{array}$ & [5] \\
\hline \multirow{4}{*}{ Assurance } & A1 & 16 & $\begin{array}{l}\text { Employees of PT. Telkom can maintain the trust } \\
\text { given by consumers }\end{array}$ & [5] \\
\hline & A2 & 17 & $\begin{array}{l}\text { Customers feel safe to use PT.Telkom products and } \\
\text { services }\end{array}$ & [5] \\
\hline & A3 & 18 & $\begin{array}{l}\text { Employees of PT. Telkom has sufficient knowledge } \\
\text { and experience }\end{array}$ & [8] \\
\hline & A4 & 19 & $\begin{array}{l}\text { Employees of PT. Telkom maintains politeness and } \\
\text { friendliness when communicatingwith consumers }\end{array}$ & [5] \\
\hline \multirow[b]{2}{*}{ Empathy } & E1 & 20 & $\begin{array}{l}\text { Employees of PT. Telkom knows the needs that } \\
\text { consumers want }\end{array}$ & [5] \\
\hline & E2 & 21 & $\begin{array}{l}\text { Employees of PT. Telkom is able to provide advice } \\
\text { to consumers to choose the type of service in } \\
\text { accordance with the needs }\end{array}$ & [6] \\
\hline
\end{tabular}




\begin{tabular}{ccrlc}
\hline Dimensions & Code & No & \multicolumn{1}{c}{ Service Attribute } & Source \\
\hline E3 & 22 & $\begin{array}{l}\text { Company employees are able to answer consumer } \\
\text { questions clearly }\end{array}$ & {$[6]$} \\
& E4 & 23 & $\begin{array}{l}\text { The company is able to provide the best solution to } \\
\text { consumer complaints }\end{array}$ & {$[6]$} \\
E5 & 24 & Employees of PT. Telkom gives a fair service & {$[8]$} \\
\hline
\end{tabular}

\subsection{Distribution of Questionnaires}

In this study the population in question is the people who use TelkomSpeedy products in the city of Semarang, which amounted to 40,596 people. In sampling there are random sampling and non-random sampling. The sampling method used is the non-random sampling is purposive sampling, because there is a requirement that the respondent is a user who has become a member.

Sampling method used is Taro Yamane method on equation 1 with a margin error of $10 \%$ and the population of 40,596 people. Based on the calculation obtained amount of sample as much as 99,75 . To facilitate the research, the number of samples to be used is 100 respondents.

\section{Results}

Based on Cartesian diagram figure 3 that goes into quadrant $\mathrm{A}$ is the main priority where the respondents feel the attribute is very important but feel dissatisfied to PT.Telkom performance. The attributes include employees of PT. Telkom is friendly in providing services, PT. Telkom responds to requests and complaints quickly, and employees of PT. Telkom is able to provide advice to consumers to choose the type of service in accordance with the needs.

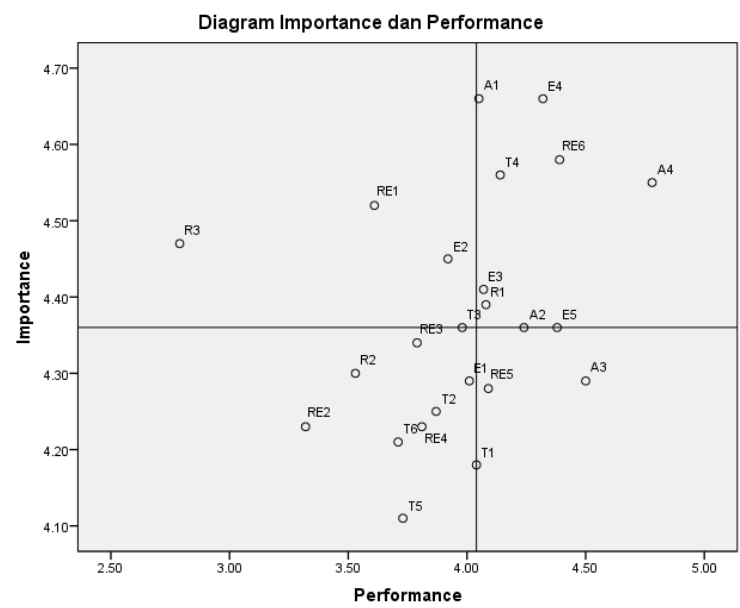

Fig. 3. Diagram of Cartesian Importance Performance.

While in quadrant B users PT.Telkom consider attribute in this quadrant is very important and very satisfactory so that this attribute is obliged to be maintained. these attributes include the results of work in accordance with the initial agreement, PT. Telkom is reliable compared to similar competitors, ease in obtaining information about products and services provided, employees of PT. Telkom can maintain the trust given by consumers, customers feel safe to use products and services PT.Telkom, employees of PT. Telkom maintains civility and friendliness when communicating with consumers, company 
employees are able to answer consumer questions clearly, and companies are able to provide the best solution to consumer complaints.

In quadrant $\mathrm{C}$ shows some less important attributes and less satisfactory, so users behave mediocre, attributes that exist in quadrant $\mathrm{C}$, among others, the quality of the results of the project carried out satisfactory (example: neat), employees of PT. Telkom wearing polite and neat clothes when work, attractive office physical facilities, comfortable waiting room, employees of PT. Telkom is friendly in responding to customer complaints, employees of PT. Telkom serves quickly and thoroughly, PT.Telkom employees are professional towards the wants and demands of consumers, employees of PT. Telkom always willing to help consumers, and employees of PT. Telkom knows the needs that consumers want.

While in the last quadrant is the quadrant $\mathrm{D}$ there is no attribute that shows less important factors but the user is very satisfied among others PT. Telkom uses up-to-date equipment in every work, PT. Telkom provides a diverse product that can be a choice of products for customers, employees of PT. Telkom has sufficient knowledge and experience, and employees of PT. Telkom gives a fair service.

Recommendations given to PT. Telkom Divre IV Central Java and Yogyakarta is the first to improve the performance of service quality attributes that are considered important by the user but its performance is still considered low, especially in quadrant A which amounted to 3 attributes (Telkom employees are friendly in providing services, PT Telkom respond to demand and complaints quickly, Telkom employees are able to advise consumers to choose the type of service in accordance with the needs), so that users do not feel disappointed and want to re-use the services of PT. Telkom.

The second recommendation is to maintain and continuously improve the performance of service quality attributes that are considered important and perform well by users, especially in the B quadrant of 8 attributes (Results of work in accordance with the initial agreement, PT Telkom reliable than similar competitors, ease in obtaining information about products and services provided, PT Telkom employees can maintain the trust given by consumers, customers feel safe to use the products and services of PT.Telkom, employees of PT Telkom maintain courtesy and friendliness when communicating with consumers, company employees able to answer consumer questions clearly, the company is able to provide the best solution to consumer complaints), so users feel satisfied and loyal to the services provided.

\section{Acknowledgment}

The authors would like to thank Telkom Divre IV Central Java \& Yogyakarta and Diponegoro University for support in this research.

\section{References}

1. M. A. Fadhillah, Analisis Kinerja Perusahaan Dilihat Dari Kepuasan Pelanggan Pada Perusahaan Kontraktor Telekomunikasi Dengan Menggunakanpendekatan Metode B2B Servqual Dan Importance Performance Analysis (IPA), (2012).

2. O. Farreza, Analisis Kepuasan Konsumen Terhadap Produk Dan Pelayanan Rumah Makan Pecel Lele Lela Bogor, (2015).

3. J. Goncalves, A. Pinto, M. Batista, A.C. Pereira, G. Ambrosano, Importanceperformance analysis: Revisiting a tool for the evaluation of clinical services, $\mathrm{H}, \mathbf{6}$, 285-291. (2014).

4. J. Martilla, J. James, Importance-Performance Analysis., JoM, 41, 77-79, (1977). 
5. J. Oscar, Analisis Kepuasan Pelanggan dengan Importance Performance Analysis di SBULaboratory Cibitung PT Sucofindo (PERSERO), JTI, 1-10. (2013).

6. A. Parasuraman, V.A. Zeithaml, L.L. Berry, A Conceptual Model of Service Quality and Its Implications for Future Research, JoM, 49, 41-50, (1985).

7. A. S. Singh, M. B. Masuku, Sampling techniques and determination of sample size inapplied statistics research: an overview, IJoECM, 11, 1-22, (2014).

8. M. YuvinaTileng, W. H Utomo, R. Latuperissa Analysis of Service Quality using Servqual Method and Importance Performance Analysis (IPA) in Population Department, Tomohon City., IJoCA, 23-30, (2013).

9. V. A. Zeithaml, , L. L. Berry, and A. Parasuraman, Communication And Control Process In The Delivery Of Service Quality., JoM, 52, 35-48, (1990). 